sciendo Порівняльна професійна педагогіка 8(2)/2018 Comparative Professional Pedagogy 8(2)/2018

DOI: $10.2478 /$ rpp-2018-0027

Professor, BOBBETTE M. MORGAN

The University of Texas Rio Grande Valley, the USA Address: One University Blvd., Brownsville, Texas 78520

E-mail: Bobbette.Morgan@utrgv.edu

$\mathrm{PhD}$, Professor, KATHY BUSSERT-WEBB

The University of Texas Rio Grande Valley, the USA

Address: One University Blvd., Brownsville, Texas 78520

E-mail: Bobbette.Morgan@utrgv.edu

MA, Research assistant, HANNAH MASSO

The University of Texas Rio Grande Valley, the USA

Address: One University Blvd., Brownsville, Texas 78520

E-mail: Bobbette.Morgan@utrgv.edu

\title{
LATINO UNDERGRADUATE PERSPECTIVES ON TRADITIONAL AND COLLABORATIVE CULMINATING PRESENTATIONS
}

\begin{abstract}
The importance of the research related to the existence of collaborative learning in higher education for Latinos, specifically pre-service teachers, has been substantiated. It has been defined that while teacher retention rates for Latinos are lower than for whites, using teamwork in the classroom might make Latinos teaching more rewarding. Most participants in the present study preferred collaborative learning as teachers. Using cognitive- and social-constructivist frameworks, the authors provide trends expressed by 371 undergraduate pre-service teachers about traditional tests and cooperative culminating experiences. Since archival data from regular collaborative pedagogies over a 10-year period have been used, the authors did not include identifying information. However, about $96 \%$ of undergraduates are first-generation Latino/college students. Students' responses to end-of-course surveys have been analyzed. The two major qualitative themes emerging from grounded theory analysis were social interaction and the cognitive domain. Quantitatively, most preferred group presentations over traditional exams. Statistically significant correlations between Variables 1 (perceived retention of material) and 2 (preferred culminating experience as future teachers), Variables 1 (perceived retention of material) and 3 (culminating experience for an easy A), and Variables 2 (preferred culminating experience as future teachers) and 3 (culminating experience for an easy A) have been found. Implications relate to designing more collaborative activities for nondominant college students. As the result of the conducted research it has been determined that collaborative learning needs to be well planned, students need to be prepared to work in groups, and teachers' expectations need to be stated explicitly if the benefits attributed to collaborative learning are to be realized.
\end{abstract}

Keywords: Latino higher education, testing and assessment, cooperative and collaborative learning, undergraduates. 
sciendo Порівняльна професійна педагогіка 8(2)/2018

Comparative Professional Pedagogy 8(2)/2018

\section{INTRODUCTION}

Collaborative learning relates to the cooperative learning model, is theory-based, much researched, and operationalized into clear procedures. Regarding theory, collaborative learning's roots emanate from theories of social interdependence and cognitive development, which align to cognitive and social constructivism (Sawyer, \& Obeid, 2017). Social interdependence theory views collaboration as resulting from positive links between individuals to accomplish a common goal. The Gestalt psychologist Kafka proposed in the early 1900's that interdependence creates groups that are dynamic wholes (Lewin, 1948). Over 900 studies validate the effectiveness of cooperative learning over competitive and individualistic efforts (Johnson, \& Johnson, 2002). For example, this approach relates to increased students' achievement and knowledge retention (Johnson \& Johnson, 2009). Johnson and Johnson's cooperative learning model focuses on five elements: positive interdependence, face-to-face interaction, individual accountability, social integration, and group processing (Sharan, 2015). In this pedagogical strategy, small, heterogeneous groups of students work together for a given period to accomplish shared learning goals, fulfilled if all group members commit to their assignments (Johnson, Johnson, \& Smith, 2014).

Scholars often discuss cooperative and collaborative learning terms interchangeably throughout the literature and have included other terms, e.g., team-based learning (Saldivar, 2015). For example, M. Andreu-Andrés (2016) studied cooperative learning activities and beliefs of 150 engineering education students in Spain; in her study, one group of students participated in a collaborative experience, while the others participated in a cooperative experience with different processes. Although some scholars state that collaborative and cooperative learning processes are dissimilar, the university students in Andreu-Andrés' study had almost identical perceptions of the process. AndreuAndrés stated active group engagement in authentic tasks should be the focus. Other models of inquiry-based learning, such as problem-based learning, share the basic educational premises of cooperative learning (Conde, Hernández-García, García-Peñalvo, Fidalgo-Blanco, \& Sein- Echaluce, 2016; Hmelo-Silver, Duncan, \& Clark, 2007; Sharan, Sharan, \& Tan, 2013).

\section{THE AIM OF THE STUDY}

The purpose of the study is to summarize, analyze, and synthesize 10 years of data collected from 371 undergraduate Latino pre-service teachers. These students participated in different education and/or reading courses, but with the same professor. Our research questions were: 1 . Which assessment format (traditional final exams or cooperative culminating presentations) do students feel helps them retain concepts better? (Variable 1) 2. Which assessment format (traditional final exams or cooperative culminating presentations) do students like better? (Variable 2) 3. Which assessment format (traditional final exams or cooperative culminating presentations) do students feel will yield them a higher grade? (Variable 3). 4. Which type of exam (traditional final exams or cooperative culminating presentations) would students use as a future teacher? 5 . What are the relationships between the above variables? 6 . What are qualitative differences between undergraduate perceptions regarding traditional final exams and cooperative culminating presentations?

\section{THEORETICAL FRAMEWORK AND RESEARCH METHODS}

This study's overarching conceptual frameworks are cognitive and social constructionism. Cognitive constructionism focuses on learners' roles in knowledge construction and their learning processes (Piaget, 2001). L. Vygotsky believed people can learn with much scaffolding from others. He created the Zone of Proximal Development (ZPD). While 
cognitive constructivism relates mostly to an individual's cognitive development, social constructivism centers on how we learn with and through others (Kozulin, 1986; Vygotsky, 1978). Piaget and Vygotsky perceived interactions with more-able peers and instructors as a result of cognitive development; both perceived learners to be agents in their learning (Sawyer, \& Obeid, 2017).

Students completed hard copies of post-group feedback forms after they gave group presentations; these surveys related to the current research questions. These forms included these questions, which did not vary for each semester that data was gathered: Question 1: Which exam format helps you to retain more long term information? Question 2: Which exam format do you like better as a teacher? Question 3: How many students in total were in the group? Rate yourself and partner(s) on a scale from one to ten. Also, add comments. Question 4: For which format is it easier to receive a test grade of an A?

Other questions on the survey, which we did not use for this research focused on the students describing what they did to prepare for the group presentations, how they interacted with peers, and how many hours they spent collaborating with peers outside of class. Other sources consist of the course syllabi, instructions for the group presentations, written instructor feedback for each group presentation, and handouts the college students designed and distributed to their peers during their presentations, e.g., BINGO, Jeopardy, and other games, role-plays, PowerPoints, and other types of presentations.

This non-experimental study used archival data at a designated Hispanic Serving Institution (HSI) from 2003 to 2013 in a city with 170,000 residents. During data gathering, approximately 14,000 students attended the university per year; over $96 \%$ were Latinos and over $87 \%$ were first-generation college students. This Texas public university, offering bachelor's, master's, and doctoral degrees, situates itself along the U.S./Mexico border. According to the U.S. Census Bureau (2010), about $33 \%$ of residents in this city lived in poverty, with a per capita income of $\$ 14,000$; approximately $87 \%$ are Spanish-speaking and $93 \%$ are Latino/a.

Data were collected from literacy and curriculum methods courses, meeting faceto-face for three contact hours per week. The courses were split about evenly for elementary and secondary pre-service teachers. There were 371 completed forms for analysis; the students completed and submitted at the end of the semester, immediately after their group presentations. The group presentations were ways peers could synthesize and teach information the instructor had taught during a semester.

No IRB approval was needed for this study because all documents were archival. Activities and assessments the instructor conducted were a normal part of instruction. Researchers removed all identifying information before data analysis began. Because all information was removed, we cannot supply specific gender or ethnicity numbers.

Following Johnson's and Johnson's model (Sharan, 2015), the instructor placed students in groups to create diversity and to develop students' academic and social skills. As part of the positive interdependence aspect of this model, each group member was to contribute to the success of the group. Thus, the instructor gave one grade to each group, but based decisions on each group member's evidence of work done. The goal was to create a community of learners and to have students synthesize, evaluate, and apply course concepts, as per Bloom's taxonomy (Anderson, \& Krathwohl, 2001).

For quantitative analysis, the researchers checked and rechecked the responses and data to ensure the data was clean. Researchers used Microsoft Word and Excel, analyzed close - ended responses using descriptive and inferential statistics utilizing the SPSS 24 Program. 
Researchers used SPSS to run descriptive statistics (Table 1). We used correlational research methods by measuring two variables and assessing the relationship between variables without manipulating an independent variable. The archival data approach to correlational research uses Pearson's $r$ (University of Minnesota Libraries Publishing, 2016). The responses to the question on the surveys were coded as ' 1 ' for a Cooperative work response, ' 2 ' for an Objective exam response, ' 3 ' for both cooperative and objective exam responses. The coded data was then run through SPSS in a Pearson's $r$ correlation.

For qualitative analysis, we analyzed students' comments based on the open-ended questions to which they replied in the survey. Researchers looked for patterns and trends vis-à-vis the research questions and theoretical frameworks. Authors used the grounded theory method of data analysis (Corbin, \& Strauss, 2008). We collapsed themes when they related to larger themes. Next, we met to discuss our individually created themes and to establish inter-rater reliability. Remarkably, we agreed on all but two sub-themes, with an inter-rater reliability of $88 \%$. We noticed for the $88 \%$ of the themes we agreed upon, we used synonyms, e.g., social interaction versus social integration, which possibly relates to our different fields. We worked individually to reanalyze the two dissimilar themes. Authors came to consensus.

\section{RESULTS}

Quantitatively, most participants preferred group presentations over traditional exams. We found statistically significant correlations between Variables 1 ("perceived retention of material") and 2 ("preferred culminating experience as future teachers"), Variables 1 ("perceived retention of material") and 3 ("culminating experience for an easy A"), and Variables 2 ("preferred culminating experience as future teachers") and 3 ("culminating experience for an easy A"). The two major qualitative themes, which are presented after the quantitative results, were social interaction and cognition. Please see the tables after references for quantitative and qualitative findings.

Quantitative Results. Based upon our analyses using SPSS, students perceived collaborative work helped them retain the most information $(88.4 \%$, Table 1). Students preferred, as future teachers, to use the collaborative work format $(76.8 \%$, Table 1). Students also thought it was easiest to get an "A" on collaborative work $(66.7 \%$, Table 1). Overall, from all three questions analyzed, students preferred collaborative work. Because some participants did not answer every question, the total number is different for each survey question in Table 1.

Table 1

\begin{tabular}{|c|c|c|c|c|c|}
\hline \multicolumn{6}{|c|}{ Descriptives } \\
\hline Question & Variable & $\begin{array}{l}\text { \# in } \\
\text { Group }\end{array}$ & Freq. & $\%$ & Total \\
\hline $\begin{array}{l}\text { Q1: Which exam format helps you } \\
\text { to retain more long term } \\
\text { information? }\end{array}$ & $\begin{array}{l}\text { Collaborative } \\
\text { (coded as } 1)\end{array}$ & & 328 & 88.4 & \\
\hline & $\begin{array}{l}\text { Objective exam } \\
\text { (coded as 2) }\end{array}$ & & 37 & 10.0 & \\
\hline & Both (coded as 3) & & 6 & 1.6 & \\
\hline & & & & & 371 \\
\hline $\begin{array}{c}\text { Q2: Which exam format do you like } \\
\text { better as a teacher? }\end{array}$ & $\begin{array}{l}\text { Collaborative } \\
\text { (coded as 1) }\end{array}$ & & 282 & 76.8 & \\
\hline
\end{tabular}


sciendo Порівняльна професійна педагогіка 8(2)/2018 Comparative Professional Pedagogy 8(2)/2018

\begin{tabular}{|c|c|c|c|c|c|}
\hline \multicolumn{6}{|c|}{ Continued } \\
\hline \multirow[t]{4}{*}{ Question } & Variable & $\begin{array}{l}\text { \# in } \\
\text { Group }\end{array}$ & Freq. & $\%$ & Total \\
\hline & $\begin{array}{l}\text { Objective exam } \\
\text { (coded as 2) }\end{array}$ & & 47 & 12.8 & \\
\hline & Both (coded as 3 ) & & 38 & 10.4 & \\
\hline & & & & & 367 \\
\hline \multirow[t]{5}{*}{$\begin{array}{l}\text { Q3: How many students in total } \\
\text { were in the group? Rate yourself } \\
\text { and partner(s) on a scale from one } \\
\text { to ten. Also, add comments. }\end{array}$} & & 1 & 23 & 5.85 & \\
\hline & & 2 & 158 & 40.0 & \\
\hline & & 3 & 190 & 48.35 & \\
\hline & & 4 & 22 & 5.6 & \\
\hline & & & & & 393 \\
\hline \multirow[t]{4}{*}{$\begin{array}{l}\text { Q4: For which format is it easier to } \\
\text { receive a test grade of an A? }\end{array}$} & $\begin{array}{l}\text { llaborative } \\
\quad(\text { coded as } 1)\end{array}$ & & 238 & 66.70 & \\
\hline & $\begin{array}{l}\text { Objective exam } \\
\text { (coded as 2) }\end{array}$ & & 109 & 30.50 & \\
\hline & Both (coded as 3) & & 10 & 2.80 & \\
\hline & & & & & 357 \\
\hline
\end{tabular}

For our first correlational analysis, we compared Question 1 (which exam format helped them to retain the most information) with Question 4 (which type of exam they would use as a future teacher). Because some participants did not answer every question, the total number is different in the three correlation analyses, shown in Table 2. This table presents the statistical results relevant to this analysis. There was a positive correlation between the two variables, $r=.23, p=.000$. Thus, a positive relationship exists between survey Questions 1 and 4. Students' preference for collaborative activities for long-term retention was significantly correlated with their desire to use collaborative activities when they became educators with their own classrooms.

The second analysis sought to determine the relationship of student preference for the exam type that would help them retain the most information (Question 1) and which type of exam students felt was easier to receive a test grade of an A (Question 3). Table 2 presents the statistics relevant to this analysis. There was a positive correlation between the two variables, $r=.12, p=.028$. Thus, a positive relationship exists between survey Questions 1 and 3. Students felt that collaborative presentations enabled them to retain the most information and that it was easier to earn an "A". A statistically significant correlation existed between these two questions, also.

The third analysis sought to determine the relationship of student preference regarding which type of exam they would use as a future teacher (Question 4) and which exam they felt was easier to receive a test grade of an A (Question 3). Table 2 presents the statistics relevant to this analysis. We found a positive correlation between the two variables, $r=.21, p=.000$. Thus, a positive relationship exists between survey Questions 3 
sciendo Порівняльна професійна педагогіка 8(2)/2018 Comparative Professional Pedagogy 8(2)/2018

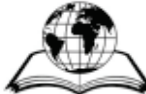

and 4. Results indicate that students felt it was easier to earn an "A" and use the collaborative presentation in their own classrooms in the future. Again, a statistically significant correlation exists between these questions.

Table 2

SPSS Correlations

\begin{tabular}{llr|r|r} 
& & \multicolumn{1}{c}{ Retain } & \multicolumn{1}{c}{ AsTeacher } & \multicolumn{1}{c}{ EasyA } \\
\hline \multirow{2}{*}{ Retain } & Pearson Correlation & 1 & $.227^{* *}$ & $.116^{*}$ \\
\cline { 2 - 5 } & Sig. (2-tailed) & & .000 & .028 \\
\cline { 2 - 5 } & $\mathrm{N}$ & 371 & 366 & 356 \\
\hline \multirow{3}{*}{ AsTeacher } & Pearson Correlation & $.227^{*}$ & 1 & $.211^{* *}$ \\
\cline { 2 - 6 } & Sig. (2-tailed) & .000 & & .000 \\
\hline \multirow{2}{*}{ EasyA } & $\mathrm{N}$ & 366 & 367 & 353 \\
& Pearson Correlation & $.116^{*}$ & $.211^{* *}$ & 1 \\
\cline { 2 - 6 } & Sig. (2-tailed) & .028 & .000 & \\
\cline { 2 - 6 } & $\mathrm{N}$ & 356 & 353 & 357 \\
\hline
\end{tabular}

${ }^{*}$. Correlation is significant at the 0.01 level (2-tailed).

* Correlation is sianificant at the 0.05 level (2-tailed)

Qualitative Results. We present qualitative results of all research questions. The student quotes (found in tables 3 through 18) highlight key sub-themes for each question. Our sub-themes represent our thorough analysis for student responses to each question. We noticed a pattern that emerged across several questions. For instance, the most salient subthemes that emerged throughout the questions were cognitive and affective domains. The next common sub-themes were multimodalities and social interaction/learned from peer/peers' help. Based on these results, it appeared that participants found the cognitive (the head), affective (the heart), social (working with others), and multimodalities (connected to the psychomotor domain) to be important aspects of collaborative learning. P. Dettmer (2006) discussed that these four domains: cognitive, affective, social, and psychomotor, are all important aspects of learning.

Next, although the overwhelming majority expressed support of collaborative learning in their written responses, some felt that it would be easier, once they became teachers, to grade objective exams consisting of multiple choice and true-false questions. Also, some students said they preferred multiple choice tests for their own classroom teaching because these objective exams took less time to prepare. As college students, some liked objective tests because they could analyze each question before selecting a response.

Question 1 (retain), Subtheme 1: Cognitive Domain

Table 3

\begin{tabular}{|c|l|}
\hline Participant & \multicolumn{1}{|c|}{ Quote } \\
\hline 48 & $\begin{array}{l}\text { "Group presentations tend to be engraved and instilled in your memory easier. I } \\
\text { am a visual learner and it helps to see these formats acted out." }\end{array}$ \\
\hline 329 & $\begin{array}{l}\text { "I think that I spent more time reviewing notes and other sources to make sure I } \\
\text { had everything O.K. so it sunk in my brain. It it would have been multiple } \\
\text { choice, I would have forgotten it the next day" }\end{array}$ \\
\hline 305 & $\begin{array}{l}\text { "Because of the extensive preparation I feel more information has been } \\
\text { converted to long-term memory" }\end{array}$ \\
\hline
\end{tabular}


Tables 3-5 provide student responses to survey Question 1: "Which [format] helps you to retain information longer?" Sub-themes that emerged were cognitive domain, multimodalities, and affective domain.

Table 4

\section{Question 1 (retain), Subtheme 2: Multimodalities}

\begin{tabular}{|c|l|}
\hline Participant & \multicolumn{1}{|c|}{ Quote } \\
\hline 351 & $\begin{array}{l}\text { "As we have learned in this and other education classes "doing" has better results } \\
\text { than merely being a passive learner" }\end{array}$ \\
\hline 319 & $\begin{array}{l}\text { "The 'Quiz Show' will help us retain the information better because it will help } \\
\text { visual and auditory learners. The questions were read aloud and I also think it is } \\
\text { a fun way to study and review for the final" }\end{array}$ \\
\hline $\begin{array}{l}\text { "Role play is the best way to absorb information, you remember better through } \\
\text { experience" }\end{array}$ \\
\hline
\end{tabular}

Question 1 (retain), Subtheme 3: Affective Domain

Table 5

\begin{tabular}{|c|l|}
\hline Participant & \multicolumn{1}{c|}{ Quote } \\
\hline 355 & $\begin{array}{l}\text { "[Presentations] are more interactive and "fun". The games make it interesting. I } \\
\text { think I remember the concepts better when we relate them to something familiar, } \\
\text { like a game" }\end{array}$ \\
\hline 69 & $\begin{array}{l}\text { "Group presentation because you are able to see how the students comprehend the } \\
\text { information instead of becoming nervous on a multiple choice test.." }\end{array}$ \\
\hline 362 & $\begin{array}{l}\text { "I am immediately intrigued when an assignment calls for my creativity and allows } \\
\text { for freedom of expression. Being able to take what you have learned and present in } \\
\text { your own style gives the students a sense of pride on two different levels. First } \\
\text { being able to show off how well they have grasped the concepts and secondly, how } \\
\text { they have taken that information and changed it into something of their own. Paper } \\
\text { tests offer nothing in self-gratification, and only call on a student's ability to } \\
\text { memorize instead of applying the knowledge" }\end{array}$ \\
\hline
\end{tabular}

Tables 6, 7, 8, and 9 provide student responses to survey Question 2: "Which exam format do you like better as a teacher?" Emerging sub-themes were cognitive domain, affective domain, social interaction, and multimodalities.

Table 6

Question 2 (like as teacher), Subtheme 1: Cognitive Domain

\begin{tabular}{|c|l|}
\hline Participant & \multicolumn{1}{|c|}{ Quote } \\
\hline 363 & "Group presentation. I want to know what they know other than memorized" \\
\hline 202 & $\begin{array}{l}\text { "I like this type of exam [group]. It give flexability [sic] for students to show there } \\
\text { [sic] strengths. The students will also have to know the information to explane [sic] } \\
\text { it to others" }\end{array}$ \\
\hline 181 & $\begin{array}{l}\text { "Group exams help students get a better knowledge of the material instead of } \\
\text { just memorizing it" }\end{array}$ \\
\hline 194 & $\begin{array}{l}\text { "Multiple choice. I like multiple choice because it helps me to analyze the choices } \\
\text { given in order to choose the correct answer" }\end{array}$ \\
\hline
\end{tabular}


sciendo Порівняльна професійна педагогіка 8(2)/2018 Comparative Professional Pedagogy 8(2)/2018

Table 7

Question 2 (like as teacher), Subtheme 2: Affective Domain

\begin{tabular}{|c|l|}
\hline Participant & \multicolumn{1}{|c|}{ Quote } \\
\hline 225 & $\begin{array}{l}\text { "I will definitely use this method to keep my student's attention and to make it } \\
\text { a fun activity for all of them while they learn and enjoy a group game" }\end{array}$ \\
\hline 239 & "Group exam. Interactive way for children to play along and not feel left out" \\
\hline 254 & $\begin{array}{l}\text { "This type of [presentation]. Working in groups and with hands-on activities } \\
\text { helps keep the interest of the students and learn by doing and having fun" }\end{array}$ \\
\hline 284 & "Group exam. Because we associate exam with stress. In this format exam=fun" \\
\hline
\end{tabular}

Table 8

Question 2 (like as teacher), Subtheme 3: Social Interaction

\begin{tabular}{|c|l|}
\hline Participant & \multicolumn{1}{c|}{ Quote } \\
\hline 208 & $\begin{array}{l}\text { "Group exam. Because it will help their social skills and will help them } \\
\text { verbalize the concept and points" }\end{array}$ \\
\hline 136 & "Cooperative learning because you learn to work with other people." \\
\hline 130 & $\begin{array}{l}\text { "Group exam. I want my students to retain information and learn social skills } \\
\text { that they will need in the "real world" }\end{array}$ \\
\hline 251 & $\begin{array}{l}\text { "This type of group work. I think that the students enjoy group work/activities } \\
\text { better and it's a great way to get them interested in topics/subjects they may not } \\
\text { enjoy. It also exposes them to different strategies and they are learning how to } \\
\text { work cooperatively. It enhances their thinking and social skills and they are } \\
\text { learning so much in the process!" }\end{array}$ \\
\hline
\end{tabular}

Table 9

\begin{tabular}{|c|l|}
\hline \multicolumn{1}{|c|}{ Question 2 (like as teacher), Subtheme 4: Multimodalities } \\
\hline Participant & \multicolumn{1}{c|}{ Quote } \\
\hline 235 & $\begin{array}{l}\text { "This type of [presentation]. I believe it is easier to assess students this way } \\
\text { because everyone has his own learning style" }\end{array}$ \\
\hline 216 & $\begin{array}{l}\text { "This type of [presentation]. It is fun and interactive and hits all three learning } \\
\text { styles: auditory, kinesthetic, and visual" }\end{array}$ \\
\hline 221 & $\begin{array}{l}\text { "This type (group) mainly because it brings in a little excitement to the class. It } \\
\text { allows the students to look, read, listen to others and maintain all information" }\end{array}$ \\
\hline
\end{tabular}

Tables 10-13 provide student responses to survey Question 3: "How many students total were in the group? Rate yourself and partner(s) on a scale of one to ten. Also, add comments." Sub-themes identified under this question include: self-reflective, learned from process or peer, division of tasks, and non-traditional student difficulties. For the latter, some students mentioned not having a car or a device (e.g., a laptop), which made it difficult to meet and to work effectively with peers in the face-to-face class. Inadequate resources may relate to the contexts of first- generation college students in a low-income city (U.S. Census Bureau, 2010). Indeed, these contexts relate to collaborative learning in which peers are expected to meet outside of class time to prepare course materials. 
sciendo Порівняльна професійна педагогіка 8(2)/2018

Table 10

\begin{tabular}{|c|l|}
\multicolumn{1}{l}{ Question 3 (rate yourself and peers), Subtheme 1: Self-reflective } \\
\hline Participant & $\begin{array}{l}\text { Quote } \\
\text { "I spent a great number of hours reading, researching and not to mention stressing } \\
\text { out. I above all feel I learned on a personal level, and to me that is an achievement. I } \\
\text { gave myself a 10" }\end{array}$ \\
\hline 340 & $\begin{array}{l}\text { "Yourself: 8. I feel that as the organizer, i did a good job of making sure that } \\
\text { everyone was on the same page and in contact with each other ... Even though } \\
\text { formatting the information took a lot of time and energy, I still feel that I should } \\
\text { have somehow helped out with coming up with the questions and answers as well. } \\
\text { This is the only thing I feel bad about" }\end{array}$ \\
\hline 344 & $\begin{array}{l}\text { "Yourself: 9. I should have given it to them earlier, but I had an emergency and I } \\
\text { couldn't" }\end{array}$ \\
\hline 189 & $\begin{array}{l}\text { Yourself: 8. "I have worked with my partner in almost all of our classes and we } \\
\text { have done presentations together before. What I like about working with her is that } \\
\text { sometimes I get so frustrated that I can't see another perspective of the problem and } \\
\text { she always clarifies it for me" }\end{array}$ \\
\hline
\end{tabular}

Table 11

Question 3 (rate yourself and peers), Subtheme 3: Learning from Process/Peers

\begin{tabular}{|c|l|}
\hline Participant & \multicolumn{1}{|c|}{ Quote } \\
\hline 80 & $\begin{array}{l}\text { Partner 1: 10. "Because, she contributed with the project and helped me when I had } \\
\text { a question" }\end{array}$ \\
\hline 120 & $\begin{array}{l}\text { Partner 1: 10. "She helped me in understanding." } \\
\text { Yourself: 10. "I help my group get a better understanding of certain strategies, and } \\
\text { shared some of my own ideas from real life experience" }\end{array}$ \\
\hline 132 & $\begin{array}{l}\text { Partner 1: 10. "My partner was very co-operative and had ideas of her own that } \\
\text { helped me" }\end{array}$ \\
\hline 41 & Partner 1: 10. "She communicated well and helped me whenever I got stuck" \\
\hline
\end{tabular}

Table 12

Question 3 (rate yourself and peers), Subtheme 4: Divided Tasks

\begin{tabular}{|c|l|}
\hline Participant & \multicolumn{1}{|c|}{ Quote } \\
320 & $\begin{array}{l}\text { Yourself: 10. "I made sure that when we were working together, we stayed on task } \\
\text { every time we met." } \\
\text { Partner 1: 10. "She helped a lot with her ideas. We worked-together very well." } \\
\text { Partner 2: 10. "He typed everything for us and helped w/ his ideas" }\end{array}$ \\
\hline 333 & $\begin{array}{l}\text { Yourself: 9 "We got together 2 times but the Thursday I was out, I was not in } \\
\text { communication with anyone."Partner 1: 10. "She was great. She did the signs that } \\
\text { we needed and contributed with questions". } \\
\text { Partner 2: 10. "She brought props and made the handouts she did an excellent job" }\end{array}$ \\
\hline 339 & $\begin{array}{l}\text { Yourself: 10. "I believe I contributed my 1/3 of the effort toward our project's } \\
\text { completion, and I emailed my portion to both group members in a timely fashion." } \\
\text { Partner 1: 10. "Did her part and also helped manage the loose ends to finalize our } \\
\text { presentation- (the last 10 \% of any project is challenging!) she helped us to stay } \\
\text { focused with helpful notes in our emails." } \\
\text { Partner 2: 10. "Worked hard to complete the other half of the questions and answers. } \\
\text { I believe her questions are creative and will help our peers to learn these concepts" }\end{array}$ \\
\hline
\end{tabular}


sciendo Порівняльна професійна педагогіка 8(2)/2018 Comparative Professional Pedagogy 8(2)/2018

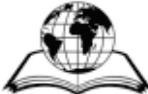

Continued

\begin{tabular}{|c|l|}
\hline Participant & \multicolumn{1}{|c|}{ Quote } \\
53 & $\begin{array}{l}\text { Yourself: 10. "I believe that I have earned full credit because we divided the work } \\
\text { evenly and we each contributed our full share. I feel that I completed my portion of } \\
\text { the project thoroughly and also helped my group members in theirs." } \\
\text { Partner 1: 10. "Deserves this rate because she helped us brain storm ideas. She } \\
\text { helped divide the workload and helped with organization." } \\
\text { Partner 2: 10. "Deserves this rate because she worked hard on her potion of the project. } \\
\text { She was willing to help at any moment and added numerous ideas to the project" }\end{array}$ \\
\hline
\end{tabular}

Table 13

Question 3 (rate yourself and peers), Subtheme 5: Nontraditional Student Difficulties

\begin{tabular}{|c|l|}
\hline Participant & \multicolumn{1}{|c|}{ Quote } \\
\hline 191 & $\begin{array}{l}\text { Yourself: 9. "I didn't have resources and didn’t have multiple dictionaries." } \\
\text { Partner 1: 10. "He made PowerPoint presentation and traveled from La Feria to } \\
\text { meet in Brownsville for preparation" }\end{array}$ \\
\hline 1 & $\begin{array}{l}\text { Yourself: [self-rating missing]"[I] Could have dedicated more time for it but family } \\
\text { circumstances did not allow it" }\end{array}$ \\
\hline 29 & $\begin{array}{l}\text { Yourself: 9. "I give myself a nine because I know I did my part and I've tried to } \\
\text { explain the best that I could for my partners to have the work done in a certain way, } \\
\text { but [peer name] is taking care of the copies and stuff. I appreciate that because I am } \\
\text { not in a very stable financial situation at the moment and every cent counts either } \\
\text { for the best or for the worse in my case" }\end{array}$ \\
\hline 329 & $\begin{array}{l}\text { Partner 2: 10. "I will give her a 10, because she made an effort to show up even though } \\
\text { she had a difficult time getting a ride. She still attended the hour appointments. In } \\
\text { the end, still managed to come through. She was able to do her part" }\end{array}$ \\
\hline $\begin{array}{l}\text { Partner 1: 9. "Even though she works, she always found the time to meet and } \\
\text { discuss the project. She called in sick to work on Monday so that we could prepare." } \\
\text { Partner 2: 9. "Even though she also works, she was able to meet with the group to } \\
\text { prepare the presentation" }\end{array}$ \\
\hline
\end{tabular}

Tables 14-18 provide student responses to survey Question 4: "For which format is it easier to receive a test grade of an A?" Sub-themes were collaborative learning is not high-stakes (a make or break grade), cognitive domain, effort, peers' help, and fairness.

Table 14

\section{Question 4 (grade of an A), Subtheme 1: Not High Stakes}

\begin{tabular}{|c|c|}
\hline rticipant & Quotes \\
\hline 7 & $\begin{array}{l}\text { roup format. It is not a one-shot deal. You get a few days to prepare and ef } \\
\text { kes a big difference, partners help" }\end{array}$ \\
\hline 370 & $\begin{array}{l}\text { cause it's less stressful, I believe that since we } \\
\text { et kind of tense" }\end{array}$ \\
\hline 315 & only nick an answer If it is the \\
\hline 12 & $\begin{array}{l}\text { play strategy kids do not have to read out questions and answer them } \\
\text { ividuals are good testers. Giving students informal tests help them shov } \\
\text { uve mastered the material" }\end{array}$ \\
\hline 325 & $\begin{array}{l}\text { s, if everyone does their part, then the grade should be an "A". In a } \\
\text { ce exam there is a lot of stress in memorizing all the concepts" }\end{array}$ \\
\hline
\end{tabular}


sciendo Порівняльна професійна педагогіка 8(2)/2018 Comparative Professional Pedagogy 8(2)/2018

Table 15

\begin{tabular}{|c|l|}
\multicolumn{2}{c}{ Question 4 (grade of an A), Subtheme 2: Cognitive Domain } \\
\hline Participant & \multicolumn{1}{c|}{ Quote } \\
\hline 363 & $\begin{array}{l}\text { "Multiple choice. Memorization, memorization! It's easier to memorize than to } \\
\text { apply understanding" }\end{array}$ \\
\hline 362 & $\begin{array}{l}\text { "Multiple choice. Obviously, the open and done format of paper tests would be best } \\
\text { way to go if you are looking for an easy grade. After several hours of repeating the } \\
\text { same words over and over again in your head, any student would be able to recall } \\
\text { the most complicated of concepts" }\end{array}$ \\
\hline 361 & $\begin{array}{l}\text { "Multiple choice. It is very easy to memorize phrases and answer as opposed to } \\
\text { group work and presentations that require a lot more work and comprehension of } \\
\text { the material" }\end{array}$ \\
\hline 339 & $\begin{array}{l}\text { "Multiple choice. I use rote memorization for most multiple-choice exams. } \\
\text { The problem is that the concepts tend not to reach my long-term memory" }\end{array}$ \\
\hline 315 & $\begin{array}{l}\text { "Group exam. Once again, with multiple-choice you only pick an answer. If it is the } \\
\text { wrong choice then you receive no credit. In a [presentation], you may have the } \\
\text { chance to explain your logic and receive partial credit" }\end{array}$ \\
\hline
\end{tabular}

Table 16

Question 4 (grade of an A), Subtheme 3: Effort

\begin{tabular}{|c|l|}
\hline Participant & \multicolumn{1}{|c|}{ Quote } \\
\hline 340 & $\begin{array}{l}\text { "Multiple choice. The answers are right there! Also, you don't have to study as } \\
\text { much for this type of an exam" } \\
335\end{array} \begin{array}{l}\text { "Multiple choice, because in a multiple choice test you have choice and if you } \\
\text { know the concept of some of the answers you can start deleting the wrong } \\
\text { answers" }\end{array}$ \\
\hline 322 & $\begin{array}{l}\text { "That's a tough one, I guess this type [presentation]. It depends on what subject or } \\
\text { topic you have. With a concept of some of the answers you can start deleting. Do } \\
\text { this type of exam. Sometimes multiple-choice exams are easier because the answer } \\
\text { is given to the student, the student does not have to research it. I guess it depends } \\
\text { on the student's learning style" }\end{array}$ \\
\hline 311 & $\begin{array}{l}\text { "Multiple choice. Because children study faster and shorter and with multiple- } \\
\text { choice they are given choices to select the correct answer" }\end{array}$ \\
\hline
\end{tabular}

Table 17

Question 4 (grade of an A), Subtheme 4: Peers Help

\begin{tabular}{|c|l|}
\hline Participant & \multicolumn{1}{|c|}{ Quote } \\
\hline 372 & $\begin{array}{l}\text { "Group presentation. The teacher can see what you do know VS. what you } \\
\text { don't. Students learn from each other and retain what they learn" }\end{array}$ \\
\hline 247 & $\begin{array}{l}\text { "This type of group. Because as a group we have the advantages of helping } \\
\text { each other, in cooperative learning" }\end{array}$ \\
\hline 369 & "Group presentation. Two heads are better than one" \\
\hline 349 & $\begin{array}{l}\text { "Group exam because you work together as a group, so it's easier to get help } \\
\text { from others when you don't understand something. Also, it is more } \\
\text { meaningful so it will probably be easier to remember" }\end{array}$ \\
\hline
\end{tabular}




\section{Sciendo Порівняльна професійна педагогіка 8(2)/2018}

Comparative Professional Pedagogy 8(2)/2018

Table 18

Question 4 (grade of an A), Subtheme 5: Fairness

\begin{tabular}{|c|l|}
\hline Participant & \multicolumn{1}{|c|}{ Quotes } \\
\hline 81 & $\begin{array}{l}\text { "I would have to say it depends, both. In multiple choice and in a group, if } \\
\text { everyone works hard, whether it be together or individually, there is a better } \\
\text { chance for success. In group, if one slacks off, but the other part [sic] in all the } \\
\text { effort he could, then changes are not so good and not fair }\end{array}$ \\
\hline 318 & $\begin{array}{l}\text { "Multiple choice, because in a [presentation] if one person doesn't do good, the } \\
\text { whole group is penalized, but in a multiple-choice exam if the student really } \\
\text { studied they, can get the "A" without having to worry about anyone else" }\end{array}$ \\
\hline 316 & $\begin{array}{l}\text { "Multiple-choice. I'm in control of my grade. Definite answers instead of } \\
\text { answers left 'to chance' during a presentation" }\end{array}$ \\
\hline
\end{tabular}

\section{CONCLUSIONS}

This study presents the perceptions of 372 undergraduate students' input on assessment formats in College of Education classes over a 10-year period. Quantitatively, we found statistically significant correlations between Variables 1 ("perceived retention of material") and 2 ("preferred culminating experience as future teachers"), Variables 1 ("perceived retention of material") and 3 ("culminating experience for an easy A"), and Variables 2 ("preferred culminating experience as future teachers") and 3 ("culminating experience for an easy A)". The two major qualitative themes were social interaction and cognitive domain. Overall, these pre-service teachers performed collaborative learning for long-term retention, for use in their future classrooms, and for an easier likelihood to receive a grade of an A. Furthermore, students were self-reflective when they evaluated themselves and peers.

Our study is important because a dearth of research exists about collaborative learning in higher education for Latinos, specifically pre-service teachers. Furthermore, because teacherretention rates for Latinos are lower than for whites (U.S. Department of Education, 2016), using teamwork in the classroom might make Latinos teaching more rewarding; most participants in the present study preferred collaborative learning as teachers.

Next, less than $50 \%$ of Latinos majoring in education receive a bachelor's degree six years after they start (U.S. Department of Education, 2016). Because of the demonstrated benefit of collaborative learning (Johnsonб \& Johnson, 2002, 2009; Sharan, 2015), perhaps more collaborative classroom experiences would motivate Latino education students to finish their degrees, as most of our participants preferred group presentations over traditional exams (Gilliesб \& Boyle, 2011). Indeed, collaboration has been effective for non-dominant students as well, including working-adult students and commuters (Barkley, Cross, \& Major, 2005). Related to diversity, collaboration can promote inclusion by increasing contact among diverse groups (Bowman, Frame, \& Kennette 2013; Kennetteб \& Frank 2013).

Collaboration also helps to develop many key skills required of students for future success. Students can develop many of these so-called "soft skills," or essential employability skills, by engaging in group work and other forms of collaboration (Ontario Ministry of Advanced Education and Skills Development, 2005). S. Adams Becker et al. (2017) discussed key trends, challenges, and developments in higher education related to the 21st century digital learning, as many of our classes are moving to hybrid and online formats. S. Adams Becker et al. (2017) stated, "Collaboration is key for scaling effective solutions. Communities of practice, multidisciplinary leadership groups, and open social 
networks can help spread evidence-based approaches". Most workplace tasks and processes require teamwork, so teaching students to work together is essential for their future success (Conde, Hernández-García, García-Peñalvo, Fidalgo-Blanco, \& Sein- Echaluce, 2016).

Furthermore, we noted that some students referred to learning styles and multiple intelligences. This related to the times in which this study took place, e.g., 2003 until 2013. During this time in curriculum and instruction, these terms were popular. Although we stand on the shoulders of theorists and practitioners before us, such as to R. Dunn (1993) for learning styles and H. Gardner (1999) for multiple intelligences, multimodalities reflect our current understanding. Multimodalities involve sounds, visuals, movements (Kress, 2003) and diverse semiotic sign systems to make and share meaning (Siegel, 2012). Cooperative multimodal activities and assessments relate to cognitive and social constructivism because they involve people's thinking, problem solving, and teamwork.

Next, the survey question asking students to rate themselves and their partners resulted in rich student comments about their own efforts and the efforts of their peers. For example, feedback was specific, detailed, and actionable. Instead of just indicating "Could be clearer." Students shared that partners should refer back to an activity experienced in class, consult a specific journal article from the professor, and identify the top three presentation items to emphasize for others to remember. This specific feedback is in line with other works that discuss benefits of collaborative groups (Johnson, Johnson, \& Smith, 2014).

Last, participants noted that collaborative learning needs to be well planned, students need to be prepared to work in groups, and teachers' expectations need to be stated explicitly if the benefits attributed to collaborative learning are to be realized. In view of this we consider it to be necessary to conduct further research concerning provision of the above stated conditions to ensure qualitative collaborative learning.

\section{REFERENCES}

1. Adams Becker, S., Cummins, M., Davis, A., Freeman, A., Hall Giesinger, C., \& Ananthanarayanan, V. (2017). NMC horizon report: 2017 higher education edition. Austin, Texas: The New Media Consortium. Retrieved from https://plato.olemiss.edu/wp-content/ uploads/sites/146/2017/02/2017-nmc-horizon-report-he-EN.pdf.

2. Anderson, L. W., \& Krathwohl, D. (2001). A taxonomy for learning, teaching and assessing: A revision of Bloom's Taxonomy of educational objectives. New York, NY: Longman.

3. Andreu-Andrés, M. Á. (2016). Cooperative or collaborative learning: Is there a difference in university students' perceptions? Aprendizaje cooperativo o colaborativo: Hay alguna diferencia en la percepción de los estudiantes universitarios? Revista Complutense de Educación, 27 (3), 1041-1060.

4. Barkley, E. F., Cross, K. P., \& Major, C. H. (2014). Collaborative learning techniques: a handbook for college faculty. Hoboken, NJ: John Wiley \& Sons.

5. Bowman, M., Frame, D. L., \& Kennette, L. N. (2013). Enhancing teaching and learning: how cognitive research can help. Journal on Excellence in College Teaching: Brain-Based Learning (Special Issue), 24 (3), 7-28.

6. Conde, M. Á., Hernández-García, Á., García-Peñalvo, F. J., Fidalgo-Blanco, Á., \& Sein- Echaluce, M. (2016). Evaluation of the CTMTC methodology for assessment of teamwork competence development and acquisition in higher education. In International 
sciendo Порівняльна професійна педагогіка 8(2)/2018 Comparative Professional Pedagogy 8(2)/2018

Conference on Learning and Collaboration Technologies (pp. 201-212). Heidelberg: Springer International Publishing.

7. Corbin, J., \& Strauss, A. (2008). Basics of qualitative research: Techniques and procedures for developing grounded theory (2nd ed.). Thousand Oaks, CA: Sage Publications, Inc.

8. Dettmer, P. (2006). New blooms in established fields: Four domains of learning and doing. Roeper Review, 28 (2), 70-82.

9. Dunn, R. S. (1993). Teaching secondary students through individual learning styles: Practical approaches for grades 7-12. Boston, MA: Allyn and Bacon.

10. Gardner, H. (1999). Intelligence reframed: Multiple intelligences for the 21st century. New York, NY: Basic Books.

11. Gillies, R. M., \& Boyle, M. (2011). Teachers' reflections of cooperative learning: a two-year follow-up. Teaching Education, 22 (1), 63-78.

12. Hmelo-Silver, C. R., Duncan, R. G. \& Clark, C. (2007) Scaffolding and achievement in problem-based and inquiry learning: a response to Kirschner, Sweller, and Clark (2006). Educational Psychologist, 42 (2), 99-107.

13. Johnson, D. W. \& Johnson, R. T. (2002). Meaningful assessment: A manageable and cooperative process. Boston: Allyn and Bacon.

14. Johnson, D. W., \& Johnson, R. T. (2009). An educational psychology success story: Social interdependence theory and cooperative learning. Educational Researcher, 38 (5), 365-379.

15. Johnson, D. W., Johnson, R. T., \& Holubec, E. J. (2010). Collaborative learning. Bandung: Nusa Media.

16. Johnson, D. W., Johnson, R. T. \& Smith, K. (2014). Cooperative learning: Improving university instruction by basing practice on validated theory. Journal on Excellence in College Teaching, 25 (3-4), 85-118.

17. Kennette, L. N., \& Frank, N. M. (2013). The value of peer-review opportunities for students in writing-intensive classes. Psychology Teaching Review, 19 (2), 106-111.

18. Kozulin, A. (Ed. and Trans.) (1986). Lev Vygotsky: thought and language. Cambridge, MA: the MIT Press.

19. Kress, G. (2003). Literacy in the new media age. NY: Routledge.

20. Lewin, K. (1948). Resolving social conflicts. New York: Harper.

21. Ontario Ministry of Advanced Education and Skills Development. (2005). Essential employability skills. Retrieved from http://www.tcu.gov.on.ca/pepg/ audiences/ colleges/progstan/essential.html.

22. Littlewood, K. E., Shilling, A. M., Stemland, C. J., Wright, E. B. \& Kirk, M. A. (2013). High-fidelity simulation is superior to case-based discussion in teaching the management of shock. Med Teach, 3 (35), 1003-1010.

$\mathrm{OH}$ : Routledge.

23. Piaget, J. (2001). The psychology of intelligence: Routledge classics. Abingdon,

24. Podsakoff, P. M., MacKenzie, S. B., Lee, J. Y., \& Podsakoff, N. P. (2003). Common method biases in behavioral research: A critical review of the literature and recommended remedies. Journal of Applied Psychology, 88 (5), 879-903.

25. Saldivar, K. M. (2015). Team-based learning: a model for democratic and culturally competent 21 st century public administrators. Journal of Public Affairs Education, 21 (2), $143-164$.

26. Sawyer, J. \& Obeid, R. (2017). Cooperative and collaborative learning: getting the best of both words. In R. Obeid, A. Schwartz, C. Shane-Simpson, \& P. J. Brooks (Eds.) 
How WE TEACH NOW: the GSTA Guide to Student-Centered Teaching. Society for the Teaching of Psychology E-Book. Retrieved from http://teachpsych.org/ebooks.

27. Siegel, M. (2012). New times for multimodality? Confronting the accountability culture. Journal of Adolescent \& Adult Literacy, 55 (8), 671-680.

28. Sharan, S., Sharan, Y., \& Tan, I. (2013). The group investigation approach to cooperative learning. In R. Chinn, C. Hmelo-Silver, A. O’Donnell, \& C. Chan (Eds.).The International Handbook of Collaborative Learning (pp. 351-369). London: Taylor and Francis.

29. Sharan, Y. (2015). Meaningful learning in the cooperative classroom. Education, (3) 13, 43 (1), 83-94.

30. University of Minnesota Libraries Publishing. (2016). Research methods in psychology. Minneapolis, MN: UM Libraries Publishers.

31. U.S. Census Bureau. (2010). Quick facts. Washington, D.C. Author.

32. U.S. Department of Education. (2016). The state of racial diversity in the educator workforce. Washington, D.C.: U.S. Department of Education, Office of Planning, Evaluation and Policy Development, Policy and Program Studies Service. Retrieved from http://www2.ed.gov/rschstat/eval/highered/racial-diversity/state-racialdiversityworkforce.pdf.

33. U.S. Department of Education, National Center for Education Statistics. (2016). Digest of education statistics. Retrieved from https://nces.ed.gov/fastfacts/display. asp? $\mathrm{id}=28$.

34. Vygotsky, L. S. (1978). Mind in society: the development of higher mental process. Cambridge, Mass: Harvard University Press. 